UNITED STATES ATOMIC ENERGY COMMISSION

ZIRCONIUM ALLOYS' FOR NUCLEAR REACTOR APPLICATIONS

By

A. D. Schwope

W. Chubb

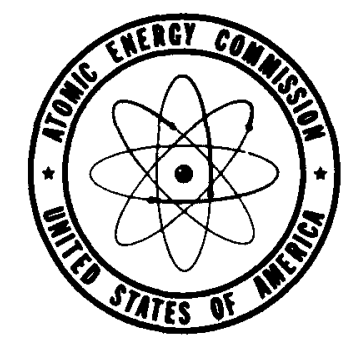

June 11, 1952

Battelle Memorial Institute Columbus, Ohio

Technical Information Service, Oak Ridge, Tennessee 


\section{DISCLAIMER}

This report was prepared as an account of work sponsored by an agency of the United States Government. Neither the United States Government nor any agency Thereof, nor any of their employees, makes any warranty, express or implied, or assumes any legal liability or responsibility for the accuracy, completeness, or usefulness of any information, apparatus, product, or process disclosed, or represents that its use would not infringe privately owned rights. Reference herein to any specific commercial product, process, or service by trade name, trademark, manufacturer, or otherwise does not necessarily constitute or imply its endorsement, recommendation, or favoring by the United States Government or any agency thereof. The views and opinions of authors expressed herein do not necessarily state or reflect those of the United States Government or any agency thereof. 


\section{DISCLAIMER}

Portions of this document may be illegible in electronic image products. Images are produced from the best available original document. 


\section{2}

Date Declassified: November 30, 1955.

This report was prepared as a scientific account of Government-sponsored work. Neither the United States, nor the Commission, nor any person acting on behalf of the Commission makes any warranty or representation, express or implied, with respect to the accuracy, completeness, or usefulness of the information contained in this report, or that the use of any information, apparatus, method, or process disclosed in this report may not infringe privatelyowned rights. The Commission assumes no liability with respect to the use of, or from damages resulting from the use of, any information, apparatus, method, or process disclosed in this report.

This report has been reproduced directly from the best availeble copy.

Issuance of this document does not constitute authority for declassification of classifled material of the same or similar content and title by the same authors.

Since nontechnical and nonessential prefatory material has been deleted, the first page of the report is page 7 .

Printed in USA, Price 20 cents. Available from the Office of Technical Services, Department of Commerce, Weshington 25, D. C. 


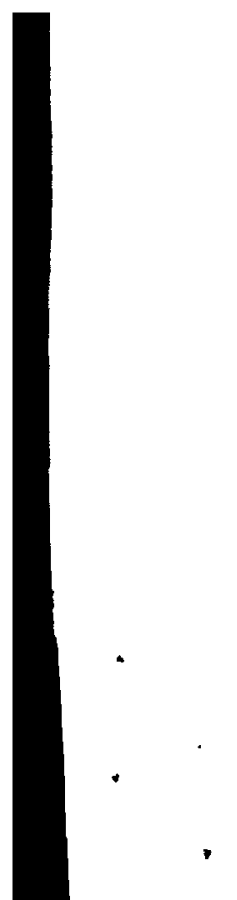

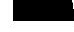

,

.

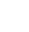

.

.

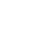


Report No. BMI-751

Contract No. W-7405-eng-92

\title{
ZIRCONIUM ALLOYS FOR NUCLEAR \\ REACTOR APPLICATIONS
}

by

\author{
A. D. Schwope \\ W. Chubb \\ June 11, 1952
}

\begin{abstract}
A number of binary and ternary zirconium-base alloy systems have been investigated in an attempt to develop a zirconium alloy for nuclear reactor applications. The tensile, hot-hardness, corrosion, and heattreating properties of these alloys have been determined.

Several zirconium-base alloys have been found with 0.2 per cent offset yield strengths at $500 \mathrm{C}$ in excess of $30,000 \mathrm{psi}$. These alloys possess various combinations of nuclear characteristics, ductility, and corrosion resistance.
\end{abstract}

\section{BATTELLE MEMORIAL INSTITUTE \\ $505 \mathrm{King}$ Avenue \\ Columbus 1, Ohio}


$-8-$

TABLE OF CONTENTS

Page

ABSTRACT . . . . . . . . . . . . . . . . . . 7

INTRODUCTION . . . . . . . . . . . . . . . . . . . 9

EXPERIMENTAL WORK . . . . . . . . . . . . . . . . 9

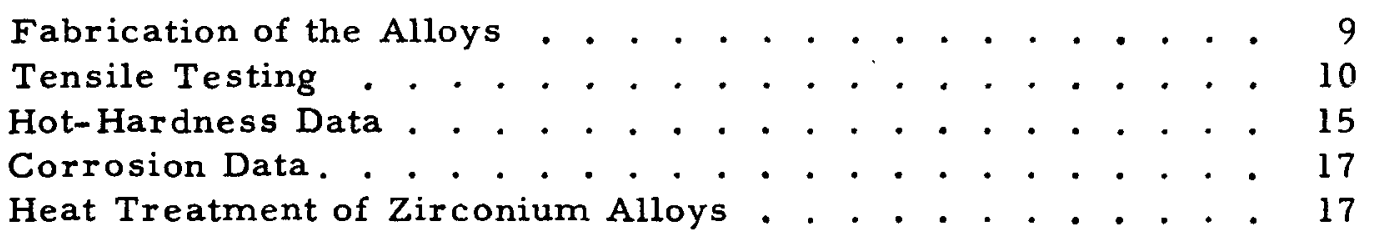

CONCLUSIONS . . . . . . . . . . . . . . . . . . 21 


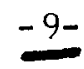

\section{INTRODUCTION}

As part of a program for the development of zirconium and zirconium alloys for nuclear-reactor applications, a search has been made for alloys having good high-temperature strength. Such alloys should have high creep resistance and low-neutron-absorption characteristics. On the assumption that these alloys might be used as structural members in place of stainless steel, Type 347, any such alloy should be as strong as stainless steel and have a much lower neutron-capture cross section.

A survey of the most likely elements for alloying with zirconium has been made, and the tensile properties of a number of binary alloys from these systems were reported in BMI-79 and BMI-718. This work indicated that aluminum, lead, molybdenum, niobium, tantalum, tin, titanium, and vanadium could all be used to strengthen zirconium effectively. It was found in the case of binary alloys that reasonable strength could be achieved only by sacrificing ductility or by increasing the thermal-neutron capture cross section of the alloy to an undesirable extent. This result stems from the fact that no element has been found as yet which has the combination of a high solubility in alpha zirconium, a low thermal-neutron capture cross section, and a satisfactorily high boiling point. It was hoped that more complex alloys might overcome this difficulty.

While the investigation of binary alloy systems of zirconium has been continued, this report describes the initial efforts to develop ternary and more complex alloys of zirconium.

\section{EXPERIMENTAL WORK}

\section{Fabrication of the Alloys}

The zirconium used in preparing the alloys mentioned in this report was Foote Mineral Company, "Grade I", iodide zirconium. The alloying elements used were of high purity. The melts were made in nonoutgassed graphite crucibles in an absolute pressure of less than 10 microns of mercury. One-half of the charge was placed in the crucible and heated by high-frequency induction. When this portion became molten, the remainder of the charge was dropped into the melt from a storage chamber. After the entire charge was molten, the melt was cooled slowly to reduce the depth of the shrinkage pipe. Approximately 10 per cent of each heat was 
lost into the graphite crucible, and the weight of the finished ingots averaged about 180 grams. The desired compositions and the actual analyses of these ingots are listed in Table 1.

The as-cast alloys were upset forged and hot rolled at $1000 \mathrm{C}$ to slabs $1 / 8$ inch thick. These slabs were cleaned by sandblasting, and examined for brittleness by shearing a small piece off the end of each slab. The brittle slabs were milled to a thickness of approximately 0.075 inch to remove surface contaminants. The more ductile slabs were cold rolled to 0. 070-inch sheet, and all materials were annealed for one hour at $700 \mathrm{C}$ in a straightening press. The resulting sheet was cleaned as necessary by milling up to 0.010 inch off each side and cut into tensile specimens. "This procedure made it possible to obtain tensile specimens from all alloys; but it should be noted that certain alloys containing molybdenum were thought to be too brittle to be cold rolled (see Table 2). Hardness data obtained during the fabrication of these alloys are shown in Table 2.

All alloys containing titanium were severely oxidized in forging and hot rolling at $1000 \mathrm{C}$. These alloys had extremely rough surfaces after sandblasting, and, in some cases, the sound metal remaining after cleaning was only 0.090 inch thick as compared with a desired hot-rolled thickness of $0.125 \mathrm{inch}$. The aluminum and nickel, binary alloys showed a tendency to crack around the edges during hot and cold rolling.

Most of the alloys containing molybdenum were found to be somewhat brittle at room temperature and no attempt was made to cold roll several of these. Of the four alloys containing molybdenum that were cold rolled, two were badly cracked. The exceptions were the $4.0 \mathrm{Sn}$ plus 0.4 Mo alloy and the $3.4 \mathrm{Sn}$ plus 0.9 Mo alloy.

\section{Tensile Testing}

The tensile specimens made from these alloys were 5 inches long and $5 / 8$ inch wide and 0.04 to 0.08 inch thick. The reduced section was 1.5 inches long and $7 / 16$ inch wide. Specimens were taken parallel to the rolling direction. These specimens were tested at $500 \mathrm{C}$ in an argon atmosphere. The speed of travel of the head of the testing machine was 0.02 inch per minute. An extensometer with a l-inch gage length and an accuracy of plus or minus $0.0001 \mathrm{inch}$ per inch was used to measure extensions. This extensometer was of the clip-on type utilizing SR-4 gages with slide bars extending out of the heated area around the specimen.

The results of these tensile tests are shown in Table 3 . The tests were run in duplicate on each alloy with the exception of the $1.8 \mathrm{Ni}$ alloy 
TABLE 1. DESIRED COMPOSITIONS AND

ANALYZED COMPOSITIONS

OF ZIRCONIUM-ALLOY INGOTS

Nominal Composition, weight per cent

Analyzed Composition*, weight per cent

\begin{tabular}{ll}
$6 \mathrm{Ti}+1 / 2 \mathrm{Al}$ & $3.6 \mathrm{Ti}+0.4 \mathrm{Al}$ \\
$6 \mathrm{Ti}+1 \mathrm{Al}$ & $4.6 \mathrm{Ti}+0.8 \mathrm{Al}$ \\
$6 \mathrm{Ti}+1 \mathrm{Mo}$ & $6.6 \mathrm{Ti}+1.1 \mathrm{Mo}$ \\
$6 \mathrm{Ti}+2 \mathrm{Mo}$ & $3.9 \mathrm{Ti}+1.9 \mathrm{Mo}$ \\
$6 \mathrm{Ti}+1 / 2 \mathrm{Nb}$ & $3.7 \mathrm{Ti}+0.6 \mathrm{Nb}$ \\
$6 \mathrm{Ti}+1 \mathrm{Nb}$ & $4.7 \mathrm{Ti}+1.3 \mathrm{Nb}$ \\
$6 \mathrm{Ti}+2 \mathrm{Sn}$ & $4.5 \mathrm{Ti}+2.0 \mathrm{Sn}$ \\
$6 \mathrm{Ti}+4 \mathrm{Sn}$ & $4.2 \mathrm{Ti}+3.9 \mathrm{Sn}$ \\
$4 \mathrm{Ti}+2 \mathrm{Sn}+1 / 2 \mathrm{Nb}$ & $2.2 \mathrm{Ti}+1.8 \mathrm{Sn}+0.4 \mathrm{Nb}$ \\
$6 \mathrm{Ti}+3 \mathrm{Sn}+1 / 2 \mathrm{Nb}$ & $3.5 \mathrm{Ti}+2.8 \mathrm{Sn}+0.8 \mathrm{Nb}$ \\
$4 \mathrm{Sn}+2 \mathrm{Ti}$ & $3.9 \mathrm{Sn}+1.6 \mathrm{Ti}$ \\
$4 \mathrm{Sn}+3 \mathrm{Ti}$ & $3.9 \mathrm{Sn}+1.2 \mathrm{Ti}$ \\
$4 \mathrm{Sn}+1 / 2 \mathrm{~V}$ & $3.7 \mathrm{Sn}+0.4 \mathrm{~V}$ \\
$4 \mathrm{Sn}+1 \mathrm{~V}$ & $5.4 \mathrm{Sn}+0.6 \mathrm{~V}$ \\
$4 \mathrm{Sn}+1 \mathrm{~V}$ & $4.3 \mathrm{Sn}+1.0 \mathrm{~V}$ \\
$4 \mathrm{Sn}+1 / 2 \mathrm{Mo}$ & $4.0 \mathrm{Sn}+0.4 \mathrm{Mo}$ \\
$4 \mathrm{Sn}+1 \mathrm{Mo}$ & $3.4 \mathrm{Sn}+0.9 \mathrm{Mo}$ \\
$4 \mathrm{Sn}+2 \mathrm{Mo}$ & $4.5 \mathrm{Sn}+1.5 \mathrm{Mo}$ \\
$4 \mathrm{Sn}+1 / 2 \mathrm{Nb}$ & $4.1 \mathrm{Sn}+0.3 \mathrm{Nb}$ \\
$4 \mathrm{Sn}+1 \mathrm{Nb}$ & $3.8 \mathrm{Sn}+1.0 \mathrm{Nb}$ \\
$1.5 \mathrm{Al}$ & $1.2 \mathrm{Al}$ \\
$2 \mathrm{Al}$ & $2.0 \mathrm{Al}$ \\
$2 \mathrm{Mo}$ & $0.9 \mathrm{Mo}$ \\
$3 \mathrm{Mo}$ & $0.9 \mathrm{Mo}$ \\
$4 \mathrm{Mo}$ & $1.2 \mathrm{Mo}$ \\
$2 \mathrm{Ni}$ & $1.8 \mathrm{Ni}$ \\
$4 \mathrm{~W}$ & $2.6 \mathrm{~W}$ \\
\hline
\end{tabular}

* These induction-melted ingots also contain 0.2 to 0.4 per cent carbon. 
TABLE 2. HARDNESS DATA FOR ZIRCONIUM ALLOYS

\begin{tabular}{|c|c|c|c|}
\hline \multirow{2}{*}{$\begin{array}{l}\text { Alloy Analysis, } \\
\text { weight per cent }\end{array}$} & \multicolumn{3}{|c|}{ Rockwell A Hardness } \\
\hline & As Cast & Cold Rolled & Annealed \\
\hline $3.6 \mathrm{Ti}+0.4 \mathrm{Al}$ & 38 & 59 & 58 \\
\hline $4.6 \mathrm{Ti}+0.8 \mathrm{Al}$ & 46 & 65 & 62 \\
\hline $6.6 \mathrm{Ti}+1.1 \mathrm{Mo}$ & 44 & 60 & 55 \\
\hline 3. $9 \mathrm{Ti}+1.9 \mathrm{Mo}$ & 43 & * & 59 \\
\hline $3.7 \mathrm{Ti}+0.6 \mathrm{Nb}$ & 47 & 57 & 51 \\
\hline $4.7 \mathrm{Ti}+1.3 \mathrm{Nb}$ & 67 & 60 & 55 \\
\hline $4.5 \mathrm{Ti}+2.0 \mathrm{Sn}$ & 45 & 62 & 58 \\
\hline 4. $2 \mathrm{Ti}+3.9 \mathrm{Sn}$ & 56 & 63 & 60 \\
\hline $2.2 \mathrm{Ti}+1.8 \mathrm{Sn}+0.4 \mathrm{Nb}$ & 50 & 57 & 54 \\
\hline $3.5 \mathrm{Ti}+2.8 \mathrm{Sn}+0.8 \mathrm{Nb}$ & 55 & 61 & 59 \\
\hline $3.9 \mathrm{Sn}+1.6 \mathrm{Ti}$ & 53 & 60 & 57 \\
\hline $3.9 \mathrm{Sn}+1.2 \mathrm{Ti}$ & 52 & 60 & 58 \\
\hline $3.7 \mathrm{Sn}+0.4 \mathrm{~V}$ & 51 & 60 & 57 \\
\hline $5.4 \mathrm{Sn}+0.6 \mathrm{~V}$ & 55 & 62 & 58 \\
\hline $4.3 \mathrm{Sn}+1.0 \mathrm{~V}$ & 53 & 60 & 57 \\
\hline $4.0 \mathrm{Sn}+0.4 \mathrm{Mo}$ & 54 & 62 & 57 \\
\hline $3.4 \mathrm{Sn}+0.9 \mathrm{Mo}$ & 66 & 64 & 58 \\
\hline $4.5 \mathrm{Sn}+1.5 \mathrm{Mo}$ & 67 & 63 & 60 \\
\hline 4. $1 \mathrm{Sn}+0.3 \mathrm{Nb}$ & 52 & 59 & 54 \\
\hline $3.8 \mathrm{Sn}+1.0 \mathrm{Nb}$ & 52 & 59 & 55 \\
\hline 1. $2 \mathrm{Al}$ & 50 & 61 & 58 \\
\hline $2.0 \mathrm{Al}$ & 37 & 59 & 57 \\
\hline $0.9 \mathrm{Mo}$ & 57 & * & 58 \\
\hline $0.9 \mathrm{Mo}$ & 61 & * & 59 \\
\hline 1. $2 \mathrm{Mo}$ & 62 & * & 59 \\
\hline $1.8 \mathrm{Ni}$ & 47 & 55 & 50 \\
\hline $2.6 \mathrm{~W}$ & 57 & 57 & 50 \\
\hline
\end{tabular}

* Not cold rolled. 
TABLE 3. TENSILE PROPERTIES OF ZIRCONIUM ALLOYS AT $500 \mathrm{C}$

\begin{tabular}{|c|c|c|c|c|c|}
\hline \multirow[b]{2}{*}{$\begin{array}{l}\text { Alloy Analysis, } \\
\text { weight per cent }\end{array}$} & \multicolumn{5}{|c|}{ Tensile Properties at $500 \mathrm{C}$} \\
\hline & $\begin{array}{c}0.2 \text { Per Cent } \\
\text { Offset } \\
\text { Yield Strength. } \\
1000 \text { psi }\end{array}$ & $\begin{array}{l}\text { Ultimate } \\
\text { Strength, } \\
1000 \text { psi }\end{array}$ & $\begin{array}{l}\text { Uniform } \\
\text { Elongation, } \\
\text { per cent }\end{array}$ & $\begin{array}{c}\text { Total } \\
\text { Elongation, } \\
\text { per cent } \\
\text { in } 1 \text { inch }\end{array}$ & $\begin{array}{l}\text { Reduction } \\
\text { of Area, } \\
\text { per cent }\end{array}$ \\
\hline $3.6 \mathrm{Ti}+0.4 \mathrm{Al}$ & 28.4 & 42.6 & 12 & 22 & 28 \\
\hline $4.6 \mathrm{Ti}+0.8 \mathrm{Al}$ & 32.2 & 46.8 & 10 & 23 & 34 \\
\hline $6.6 \mathrm{Ti}+1.1 \mathrm{Mo}$ & 33.0 & 40.8 & 4 & 17 & 23 \\
\hline $3.9 \mathrm{Ti}+1.9 \mathrm{Mo}$ & 37.6 & 52.5 & 3 & 30 & 57 \\
\hline $3.7 \mathrm{Ti}+0.6 \mathrm{Nb}$ & 18.2 & 33.6 & 12 & 38 & 45 \\
\hline $4.7 \mathrm{Ti}+1.3 \mathrm{Nb}$ & 21.6 & 34.8 & 9 & 16 & 20 \\
\hline $4.5 \mathrm{Ti}+2.0 \mathrm{Sn}$ & 25.6 & 42.4 & 9 & 28 & 34 \\
\hline $4.2 \mathrm{Ti}+3.9 \mathrm{Sn}$ & 32.0 & 50.0 & 10 & 18 & 22 \\
\hline $2.2 \mathrm{Ti}+1.8 \mathrm{Sn}+0.4 \mathrm{Nb}$ & 21.5 & 37.8 & 13 & 27 & 30 \\
\hline $3.5 \mathrm{Ti}+2.8 \mathrm{Sn}+0.8 \mathrm{Nb}$ & 28.7 & 44.3 & 11 & 24 & 31 \\
\hline $3.9 \mathrm{Sn}+1.6 \mathrm{Ti}$ & 28.1 & 42.6 & 9 & 35 & 34 \\
\hline $3.9 \mathrm{Sn}+1.2 \mathrm{Ti}$ & 25.4 & 38.8 & 14 & 29 & 35 \\
\hline $3.7 \mathrm{Sn}+0.4 \mathrm{~V}$ & 25.1 & 38.2 & 14 & 37 & 52 \\
\hline $5.4 \mathrm{Sn}+0.6 \mathrm{~V}$ & 38.7 & 54.7 & 8 & 16 & 21 \\
\hline $4.3 \mathrm{Sn}+1.0 \mathrm{~V}$ & 30.2 & 41.1 & 10 & 25 & 36 \\
\hline $4.0 \mathrm{Sn}+0.4 \mathrm{Mo}$ & 25.3 & 37.2 & 15 & 48 & 56 \\
\hline $3.4 \mathrm{Sn}+0.9 \mathrm{Mo}$ & 27.8 & 37.1 & 6 & 26 & 34 \\
\hline $4.5 \mathrm{Sn}+1.5 \mathrm{Mo}$ & 38.1 & 52.5 & 7 & 27 & 36 \\
\hline $4.1 \mathrm{Sn}+0.3 \mathrm{Nb}$ & 24.2 & 35.7 & 16 & 32 & 22 \\
\hline $3.8 \mathrm{Sn}+1.0 \mathrm{Nb}$ & 25.3 & 37.0 & 19 & 40 & 44 \\
\hline $1.2 \mathrm{Al}$ & 23.5 & 37.5 & 15 & 34 & 41 \\
\hline $2.0 \mathrm{Al}$ & 32.0 & 46.1 & 11 & 25 & 38 \\
\hline 0.9 Mo & 30.0 & 43.5 & 2 & 21 & 54 \\
\hline $0.9 \mathrm{Mo}$ & 29.9 & 42.5 & 3 & 27 & 60 \\
\hline 1. $2 \mathrm{Mo}$ & 35.8 & 48.0 & 2 & 44 & 58 \\
\hline $1.8 \mathrm{Ni}$ & 7.8 & 14.4 & 13 & 82 & 64 \\
\hline $2.6 \mathrm{~W}$ & 13.3 & 19.1 & 8 & 50 & 56 \\
\hline
\end{tabular}


and the results shown in Table 3 represent the average values obtained from these tests. The values listed under "Uniform Elongation" represent the total elastic and plastic deformation at maximum load.

These data indicate that aluminum, molybdenum, and tin are effective in improving the high-temperature strength of the zirconium-titanium solid solution, but that niobium is quite ineffective. Relatively small amounts of aluminum and molybdenum seem to strengthen the zirconium-titanium solid solution as much as large amounts of tin.

The data also show that titanium, vanadium, and molybdenum are effective in improving the high-temperature strength of the zirconium-tin alloy system, but that niobium is quite ineffective.

The data on the binary alloys show that aluminum and molybdenum are very effective in strengthening zirconium, but that nickel and tungsten have little, if any, effect upon the strength of zirconium at $500 \mathrm{C}$.

An interesting effect is to be noted in connection with most of the alloys containing molybdenum. These alloys were rather brittle at room temperature after hot rolling at $1000 \mathrm{C}$, were not cold rolled, and even after annealing for 1 hour at $700 \mathrm{C}$, they exhibited low uniform elongations in tensile tests at $500 \mathrm{C}$. And yet, these alloys produced total elongations and reductions of area on the order of 40 per cent.

It has been fairly well established that most of the body-centered cubic metals depress the beta-to-alpha transformation of zirconium, and that certain of them, particularly molybdenum and niobium, depress the transformation to temperatures where the reaction by diffusion becomes extremely sluggish. This sluggishness tends to result in the retention of a certain amount of supersaturated material on cooling of the se alloys from above the transformation range. Furthermore, this sluggishness accentuates the martensite reaction in zirconium alloys containing these elements, such that the martensite needles produced are extremely fine. In addition, the martensite reaction seems to be retarded, such that, in effect, a certain percentage of body-centered cubic zirconium is retained at room temperature on rapid cooling of these alloys from the beta range. Whether or not the "martensite-start-temperature" actually is depressed and whether it can be depressed to room temperature is not known.

In any event, the extraordinary behavior of this type of "quenched" alloy is the result of its unstable character. The alloys were brittle at room temperature after hot rolling largely because of their martensitic structure and, possibly, partially because of their condition of imminent precipitation. After annealing at $700 \mathrm{C}$, the alloys were slightly more ductile because of coarsening of the structure and partial precipitation. 
And in tensile testing at $500 \mathrm{C}$, after a certain amount of deformation was introduced, the precipitation processes were reactivated and the alloys lost their brittleness quite rapidly. This is confirmed in part by the fact that the broken tensile specimens of the binary zirconium-molybdenum series were slightly softer after testing at $500 \mathrm{C}$ than after annealing for one hour at $700 \mathrm{C}$. The value of such an alloy is directly proportional to its ability to resist decomposition at the operating temperature.

In order to compare these alloys for nuclear-reactor applications, the thermal-neutron capture cross section of each alloy was calculated by the method described in BMI-79. This method assumes that the "cross section" of an alloy is the integral of the "cross section" of every atom in a unit volume of the alloy divided by the number of atoms in that unit. These theoretical thermal-neutron capture cross sections are listed in Table 4. The "cross-section ratio" listed in Table 4 is the cross section of the alloy divided by the cross section of stainless steel, Type 347 . The "yield-strength ratio" shown in Table 4 is the yield strength of the alloy at $500 \mathrm{C}$ divided by the yield strength of Type 347 stainless steel $(31,000$ psi at $500 \mathrm{C}$ ).

Analysis of Table 4 discloses four alloys with thermal-neutron capture cross-section ratios less than 0.10 and yield-strength ratios greater than 1.0. These alloys are the $5.4 \mathrm{Sn}+0.6 \mathrm{~V}$ alloy, the $4.5 \mathrm{Sn}+1.5 \mathrm{Mo}$ alloy, the 2.0 Al alloy, and the 1.2 Mo alloy. Larger heats of alloys of approximately the se compositions will be prepared and examined for creep resistance.

\section{Hot-Hardness Data}

Diamond-pyramid hardnesses of each of the alloys were obtained at elevated temperatures by means of a vacuum hot-hardness machine. The vacuum chamber contains a stationary diamond indenter mounted over a hydraulically operated ceramic stage. The indenter, specimen, and stage are heated by open wire heating coils immediately surrounding them. A thermocouple mounted in the center of the stage records the temperature of the specimen which can be moved across by an indexing mechanism. Indentations are made by raising the hydraulic stage; and the indenter load, 500 grams, is measured by the hydraulic pressure required to raise the stage from "no load" to "full load". A cycle from "no load" to "full load" to "no load" requires about 30 seconds so that the load is applied for about 15 seconds for each indentation.

In these tests, five indentations were made at room temperature, $204 \mathrm{C}, 316 \mathrm{C}$, and $427 \mathrm{C}$; four indentations were made at $482 \mathrm{C}$ and $538 \mathrm{C}$; 
TABLE 4. PROPERTIES OF ZIRCONIUM ALLOYS COMPARED WITH PROPER TIES OF STAINLESS STEEL AT $500 \mathrm{C}$

\begin{tabular}{|c|c|c|c|}
\hline $\begin{array}{c}\text { Alloy } \\
\text { Analysis, } \\
\text { weight per cent }\end{array}$ & $\begin{array}{c}\text { Thermal-Neutron } \\
\text { Capture } \\
\text { Cross Section* } \\
\text { barns/atom }\end{array}$ & $\begin{array}{l}\text { Cross- } \\
\text { Section } \\
\text { Ratio }\end{array}$ & $\begin{array}{l}\text { Yield- } \\
\text { Strength } \\
\text { Ratio }\end{array}$ \\
\hline Stainless Steel, Type 347 & 2. 86 & 1 & 1 \\
\hline Induction-Melted Zirconium & 0.20 & 0.070 & 0.3 \\
\hline $3.6 \mathrm{Ti}+0.4 \mathrm{Al}$ & 0.56 & 0.196 & 0.92 \\
\hline $4.6 \mathrm{Ti}+0.8 \mathrm{Al}$ & 0.66 & 0.231 & 1.04 \\
\hline $6.6 \mathrm{Ti}+1.1 \mathrm{Mo}$ & 0.90 & 0.315 & 1.06 \\
\hline $3.9 \mathrm{Ti}+1.9 \mathrm{Mo}$ & 0.64 & 0.224 & 1.21 \\
\hline $3.7 \mathrm{Ti}+0.6 \mathrm{Nb}$ & 0.58 & 0.203 & 0.59 \\
\hline 4. $7 \mathrm{Ti}+1.3 \mathrm{Nb}$ & 0.69 & 0.251 & 0.70 \\
\hline $4.5 \mathrm{Ti}+2.0 \mathrm{Sn}$ & 0.66 & 0.231 & 0.83 \\
\hline 4. $2 \mathrm{Ti}+3.9 \mathrm{Sn}$ & 0.64 & 0.224 & 1.03 \\
\hline $2.2 \mathrm{Ti}+1.8 \mathrm{Sn}+0.4 \mathrm{Nb}$ & 0.43 & 0.150 & 0.69 \\
\hline $3.5 \mathrm{Ti}+2.8 \mathrm{Sn}+0.8 \mathrm{Nb}$ & 0.57 & 0.198 & 0.93 \\
\hline $3.9 \mathrm{Sn}+1.6 \mathrm{Ti}$ & 0.38 & 0.133 & 0.91 \\
\hline $3.9 \mathrm{Sn}+1.2 \mathrm{Ti}$ & 0.34 & 0.119 & 0.82 \\
\hline $3.7 \mathrm{Sn}+0.4 \mathrm{~V}$ & 0.24 & 0.084 & 0.81 \\
\hline $5.4 \mathrm{Sn}+0.6 \mathrm{~V}$ & 0.26 & 0.091 & 1.25 \\
\hline $4.3 \mathrm{Sn}+1.0 \mathrm{~V}$ & 0.29 & 0.101 & 0.97 \\
\hline 4. $0 \mathrm{Sn}+0.4 \mathrm{Mo}$ & 0.23 & 0.080 & 0.82 \\
\hline $3.4 \mathrm{Sn}+0.9 \mathrm{Mo}$ & 0.23 & 0.080 & 0.90 \\
\hline $4.5 \mathrm{Sn}+1.5 \mathrm{Mo}$ & 0.25 & 0.087 & 1.23 \\
\hline $4.1 \mathrm{Sn}+0.3 \mathrm{Nb}$ & 0.22 & 0.077 & 0.78 \\
\hline $3.8 \mathrm{Sn}+1.0 \mathrm{Nb}$ & 0.23 & 0.080 & 0.82 \\
\hline 1. $2 \mathrm{Al}$ & 0.20 & 0.070 & 0.76 \\
\hline $2.0 \mathrm{Al}$ & 0.20 & 0.070 & 1.03 \\
\hline $0.9 \mathrm{Mo}$ & 0.22 & 0.077 & 0.97 \\
\hline $0.9 \mathrm{Mo}$ & 0.22 & 0.077 & 0.96 \\
\hline 1. $2 \mathrm{Mo}$ & 0.23 & 0.080 & 1.15 \\
\hline $1.8 \mathrm{Ni}$ & 0.32 & 0.112 & 0.25 \\
\hline $2.6 \mathrm{~W}$ & 0.43 & 0.150 & 0.43 \\
\hline
\end{tabular}

* Based on 0. 20 barns/atom for $\mathrm{Zr}$. 
and three indentations were made at $649 \mathrm{C}, 704 \mathrm{C}, 760 \mathrm{C}$, and $816 \mathrm{C}$. The hardness numbers obtained from these indentations were averaged and plotted on a logarithmic scale versus temperature on a linear scale. Smooth curves were drawn through the points, and values selected from these curves appear in Table 5.

These data indicate that tin and aluminum are effective in strengthening the titanium solid solution at $700 \mathrm{C}$, and that niobium and molybdenum are quite impotent at these temperatures. The data also indicate that vanadium has a beneficial effect upon the strength of the zirconium-tin alloy system at $700 \mathrm{C}$, while titanium, molybdenum, and niobium have very little effect. It is quite apparent that the marked strengthening effect of molybdenum upon zirconium and its alloys at low temperatures is lost almost entirely between $500 \mathrm{C}$ and $700 \mathrm{C}$. Presumably, this is the temperature range in which decomposition of supersaturated solutions of molybdenum in zirconium occurs with the introduction of very little cold work.

\section{Corrosion Data}

Small pieces of each alloy were corroded in a stainless steel retort in water at $360 \mathrm{C}$.

At the end of 370 hours, all of the ternary alloys containing titanium and all of the binary alloys containing aluminum, molybdenum, nickel, and tungsten were badly corroded and had to be removed from the retort. In addition, the $4.5 \mathrm{Sn}+1.5 \mathrm{Mo}$ alloy and the $4.1 \mathrm{Sn}+0.3 \mathrm{Nb}$ alloy were badly corroded at the end of 370 hours and were removed from test.

At the end of 720 hours, the $4.0 \mathrm{Sn}+0.4$ Mo alloy and the $4.3 \mathrm{Sn}+$ 1. $0 \mathrm{~V}$ alloy were badly corroded and were removed from test.

The $3.4 \mathrm{Sn}+0.9$ Mo alloy, the $3.8 \mathrm{Sn}+1.0 \mathrm{Nb}$ alloy, the $3.7 \mathrm{Sn}+$ $0.4 \mathrm{~V}$ alloy and the $5.4 \mathrm{Sn}+0.6 \mathrm{~V}$ alloy satisfactorily survived 720 hours in water at $360 \mathrm{C}$.

\section{Heat Treatment of Zirconium Alloys}

The hardnesses of all alloys were determined in the as-cast condition, in the cold-rolled ( or hot-rolled) and annealed condition, as brine quenched from $955 \mathrm{C}$ from a gettered Vycor tube, and as brine quenched from $955 \mathrm{C}$ and heated for 6 hours at $540 \mathrm{C}$ and furnace cooled. Microstructures of all alloys were examined in the cold-rolled (or hot-rolled) and annealed 
TABLE 5. HOT-HARDNESS DATA

\begin{tabular}{|c|c|c|c|c|c|c|}
\hline \multirow{2}{*}{$\begin{array}{l}\text { Zirconium-Alloy } \\
\text { Analysis, } \\
\text { weight per cent }\end{array}$} & \multicolumn{6}{|c|}{ Diamond-Pyramid Hardness Number } \\
\hline & $\begin{array}{c}\text { Room } \\
\text { Temperature }\end{array}$ & $300 \mathrm{C}$ & $500 \mathrm{C}$ & $600 \mathrm{C}$ & $700 \mathrm{C}$ & $800 \mathrm{C}$ \\
\hline $3.6 \mathrm{Ti}+0.4 \mathrm{Al}$ & 161 & 131 & 101 & 71 & 32 & 20 \\
\hline $4.6 \mathrm{Ti}+0.8 \mathrm{Al}$ & 265 & 235 & 212 & 160 & 61 & 19 \\
\hline $6.6 \mathrm{Ti}+1.1 \mathrm{Mo}$ & 220 & 175 & 140 & 72 & 22 & 6 \\
\hline $3.9 \mathrm{Ti}+1.9 \mathrm{Mo}$ & 380 & 320 & 225 & 90 & 28 & 12 \\
\hline $3.7 \mathrm{Ti}+0.6 \mathrm{Nb}$ & 225 & 138 & 95 & 56 & 22 & 10 \\
\hline $4.7 \mathrm{Ti}+1.3 \mathrm{Nb}$ & 270 & 150 & 93 & 48 & 19 & 8 \\
\hline 4. $5 \mathrm{Ti}+2.0 \mathrm{Sn}$ & - & - & - & - & 67 & 22 \\
\hline $4.2 \mathrm{Ti}+3.9 \mathrm{Sn}$ & 345 & 270 & 208 & 147 & 45 & - \\
\hline $2.2 \mathrm{Ti}+1.8 \mathrm{Sn}+0.4 \mathrm{Nb}$ & 270 & 175 & 120 & 82 & 43 & 21 \\
\hline $3.5 \mathrm{Ti}+2.8 \mathrm{Sn}+0.8 \mathrm{Nb}$ & 220 & 188 & 140 & 95 & 44 & 16 \\
\hline $3.9 \mathrm{Sn}+1.6 \mathrm{Ti}$ & 250 & 205 & 140 & 75 & 34 & 17 \\
\hline $3.9 \mathrm{Sn}+1.2 \mathrm{Ti}$ & 190 & 140 & 110 & 82 & 37 & 15 \\
\hline $3.7 \mathrm{Sn}+0.4 \mathrm{~V}$ & 225 & 170 & 132 & 90 & 50 & 30 \\
\hline $5.4 \mathrm{Sn}+0.6 \mathrm{~V}$ & 245 & 188 & 150 & 100 & 56 & 29 \\
\hline $4.3 \mathrm{Sn}+1.0 \mathrm{~V}$ & 217 & 176 & 142 & 105 & 61 & 30 \\
\hline $4.0 \mathrm{Sn}+0.4 \mathrm{Mo}$ & 197 & 170 & 127 & 80 & 41 & 22 \\
\hline $3.4 \mathrm{Sn}+0.9 \mathrm{Mo}$ & 280 & 210 & 140 & 76 & 30 & 11 \\
\hline $4.5 \mathrm{Sn}+1.5 \mathrm{Mo}$ & 315 & 267 & 185 & 120 & 50 & 22 \\
\hline 4. $1 \mathrm{Sn}+0.3 \mathrm{Nb}$ & 250 & 152 & 108 & 78 & 45 & 21 \\
\hline $3.8 \mathrm{Sn}+1.0 \mathrm{Nb}$ & 212 & 168 & 118 & 61 & 31 & 15 \\
\hline 1. $2 \mathrm{Al}$ & 205 & 127 & 90 & 56 & 30 & 15 \\
\hline 2. $0 \mathrm{Al}$ & 225 & 185 & 150 & 80 & 36 & 17 \\
\hline $0.9 \mathrm{Mo}$ & 320 & 270 & 195 & 75 & 28 & 11 \\
\hline $0.9 \mathrm{Mo}$ & 250 & 212 & 150 & 66 & 26 & 12 \\
\hline $1.2 \mathrm{Mo}$ & 240 & 180 & 120 & 63 & 27 & 12 \\
\hline 1. $8 \mathrm{Ni}$ & 180 & 97 & 62 & 43 & 21 & 6 \\
\hline $2.6 \mathrm{~W}$ & 208 & 170 & 94 & 62 & 39 & 28 \\
\hline
\end{tabular}


condition, and as brine quenched from $955 \mathrm{C}$. This temperature was picked as a temperature at which most zirconium alloys would transform to the body-centered cubic allotrope, and any alloys that did not transform would be evident. Likewise, $540 \mathrm{C}$ was selected as a temperature at which unstable structures produced in quenching should begin to recrystallize, retained beta could be distinguished from alpha, and any alloy that did not soften could be selected for possible use in the heat-treated condition.

The hardnesses of the alloys in the as-cast condition are given in Table 2. The hardnesses of the alloys as cold rolled and annealed, as quenched from $955 \mathrm{C}$, and as quenched and aged are shown in Table 6.

It is interesting to note that most of the alloys containing bodycentered cubic alloying elements show considerable hardening on quenching from $955 \mathrm{C}$. The tin-vanadium ternary alloys seem to be notable exceptions to this rule. This hardening effect may be associated with the degree of lowering of the transformation temperature, since, within limits, the higher the quenching temperature above the transformation temperature, the harder zirconium becomes.

It is also interesting to note that most of the alloys maintained their as-quenched hardnesses to a great extent after heating at $540 \mathrm{C}$. Exceptions are the molybdenum binary alloys and the titanium-molybdenum ternary alloys.

In the annealed condition, most of these alloys showed traces of a second phase other than the carbide. The $3.6 \mathrm{Ti}+0.4 \mathrm{Al}$ alloy was a single-phase alloy. Likewise, the $4.5 \mathrm{Ti}+2.0 \mathrm{Sn}$ and the $4.2 \mathrm{Ti}+3.9 \mathrm{Sn}$ alloys were single-phase structures. The $1.8 \mathrm{Ni}$ alloy contained a great quantity of second phase, and the $2.6 \mathrm{~W}$ alloy, apparently, was largely alpha zirconium plus a dispersion of zirconium-tungsten-carbide. No hydrides were observed in any of these vacuum-melted alloys.

As quenched from $955 \mathrm{C}$, all the alloys developed structures indicating that they had been quenched from the body-centered cubic structure. These structures ranged from beta grains containing one or two martensitic needles to coarse Widmanstätten grains. The alloys containing molybdenum tended to show the least amount of transformation. On aging at $540 \mathrm{C}$, these molybdenum alloys transformed by precipitation producing a very fine-grained structure within the parent beta structure. 
TABLE 6. HEAT-TREATING DATA

\begin{tabular}{|c|c|c|c|}
\hline \multirow[b]{2}{*}{$\begin{array}{c}\text { Zirconium-Alloy } \\
\text { Analysis, } \\
\text { weight per cent }\end{array}$} & \multicolumn{3}{|c|}{ Rockwell A Hardnesses } \\
\hline & $\begin{array}{l}\text { Annealed at } \\
700 \mathrm{C} \text { for } \\
1 \text { Hour }\end{array}$ & $\begin{array}{c}\text { Brine Quenched } \\
\text { From } \\
955 \mathrm{C}\end{array}$ & $\begin{array}{c}\text { Brine Quenched } \\
\text { From } 955 \mathrm{C} \\
\text { and Aged } 6 \text { Hours } \\
\text { at } 540 \mathrm{C}\end{array}$ \\
\hline $3.6 \mathrm{Ti}+0.4 \mathrm{Al}$ & 58 & - & - \\
\hline $4.6 \mathrm{Ti}+0.8 \mathrm{Al}$ & 62 & 69 & 70 \\
\hline $6.6 \mathrm{Ti}+1.1 \mathrm{Mo}$ & 55 & 69 & 64 \\
\hline $3.9 \mathrm{Ti}+1.9 \mathrm{Mo}$ & 59 & 72 & 63 \\
\hline $3.7 \mathrm{Ti}+0.6 \mathrm{Nb}$ & 51 & 65 & 65 \\
\hline $4.7 \mathrm{Ti}+1.3 \mathrm{Nb}$ & 55 & 68 & 67 \\
\hline $4.5 \mathrm{Ti}+2.0 \mathrm{Sn}$ & 58 & 63 & 63 \\
\hline $4.2 \mathrm{Ti}+3.9 \mathrm{Sn}$ & 60 & 68 & 67 \\
\hline $2.2 \mathrm{Ti}+1.8 \mathrm{Sn}+0.4 \mathrm{Nb}$ & 54 & 66 & 64 \\
\hline $3.5 \mathrm{Ti}+2.8 \mathrm{Sn}+0.8 \mathrm{Nb}$ & 59 & 62 & 59 \\
\hline $3.9 \mathrm{Sn}+1.6 \mathrm{Ti}$ & 57 & 55 & 55 \\
\hline $3.9 \mathrm{Sn}+1.2 \mathrm{Ti}$ & 58 & 54 & 54 \\
\hline $3.7 \mathrm{Sn}+0.4 \mathrm{~V}$ & 57 & 60 & 62 \\
\hline $5.4 S n+0.6 V$ & 58 & 56 & 55 \\
\hline $4.3 \mathrm{Sn}+1.0 \mathrm{~V}$ & 57 & 62 & 63 \\
\hline 4. $0 \mathrm{Sn}+0.4 \mathrm{Mo}$ & 57 & 66 & 65 \\
\hline $3.4 \mathrm{Sn}+0.9 \mathrm{Mo}$ & 58 & 69 & 67 \\
\hline 4. $5 \mathrm{Sn}+1.5 \mathrm{Mo}$ & 60 & 69 & 67 \\
\hline 4. $1 \mathrm{Sn}+0.3 \mathrm{Nb}$ & 54 & 54 & 54 \\
\hline $3.8 \mathrm{Sn}+1.0 \mathrm{Nb}$ & 55 & 61 & 62 \\
\hline 1. $2 \mathrm{Al}$ & 58 & 54 & 53 \\
\hline 2. $0 \mathrm{Al}$ & 57 & 62 & 61 \\
\hline $0.9 \mathrm{Mo}$ & 58 & 77 & 66 \\
\hline $0.9 \mathrm{Mo}$ & 59 & 71 & 62 \\
\hline 1. $2 \mathrm{Mo}$ & 59 & 69 & 64 \\
\hline 1. $8 \mathrm{Ni}$ & 50 & 57 & 55 \\
\hline $2.6 \mathrm{~W}$ & 50 & 57 & 57 \\
\hline
\end{tabular}




\section{CONCLUSIONS}

1. Aluminum, molybdenum, and tin are effective in strengthening the zirconium-titanium solid solution at $500 \mathrm{C}$.

2. Molybdenum, titanium, and vanadium are effective in strengthening the zirconium-tin alloys at elevated temperatures.

3. Nickel and tungsten in induction-melted alloys of zirconium have very little effect upon its strength at $500 \mathrm{C}$.

4. Molybdenum depresses the transformation of zirconium such that the martensite reaction in zirconium is accentuated and such that zirconium alloys containing molybdenum tend to be supersaturated, unstable or "metastable" alloys.

5. An alloy containing approximately 4 per cent titanium and 1 per cent aluminum was found to have a yield strength at $500 \mathrm{C}$ of approximately $30,000 \mathrm{psi}$. This alloy appears to have favorable nuclear characteristics and to be relatively ductile and stable at $500 \mathrm{C}$. It is not corrosion resistant to water at $360 \mathrm{C}$.

6. An alloy containing approximately 4 per cent titanium and 2 per cent molybdenum was found to have a yield strength at $500 \mathrm{C}$ of greater than $735,000 \mathrm{psi}$. This alloy appears to have favorable nuclear characteristics. However, this alloy is somewhat brittle at room temperature and may be unstable at $500 \mathrm{C}$. It is not corrosion resistant to water at $360 \mathrm{C}$.

7. An alloy containing approximately 4 per cent titanium and 4 per cent tin was found to have a yield strength at $500 \mathrm{C}$ of approximately 30,000 psi. This alloy appears to have favorable nuclear characteristics and to be relatively ductile and stable at $500 \mathrm{C}$. It is not corrosion resistant to water at $360 \mathrm{C}$.

8. An alloy containing approximately 5 per cent tin and 1 per cent vanadium was found to have a yield strength at $500 \mathrm{C}$ of approximately $30,000 \mathrm{psi}$. This alloy appears to have very favorable nuclear characteristics. The alloy is relatively ductile and stable at $500 \mathrm{C}$, and seems to be corrosion resistant to water at $360 \mathrm{C}$.

9. An alloy containing 4.5 per cent tin and 1.5 per cent molybdenum was found to have a yield strength at $500 \mathrm{C}$ of greater than $35,000 \mathrm{psi}$. This 
alloy appears to have very favorable nuclear characteristics. The alloy seems to have some ductility, but may be unstable at $500 \mathrm{C}$. Its corrosion resistance to water has not been established.

10. An alloy containing 2 per cent aluminum was found to have a yield strength at $500 \mathrm{C}$ of approximately $30,000 \mathrm{psi}$. This alloy appears to have extremely favorable nuclear characteristics, and to be relatively ductile and stable at $500 \mathrm{C}$. It is not corrosion resistant to water at $360 \mathrm{C}$.

11. An alloy containing 1.2 per cent molybdenum was found to have a yield strength at $500 \mathrm{C}$ of greater than 35,000 psi. This alloy appears to have extremely favorable nuclear characteristics. However, this alloy is somewhat brittle at room temperature and probably is unstable at $500 \mathrm{C}$. Its corrosion resistance has not been established. 